\title{
INTERTROPICAL CINGULATES (MAMMALIA, XENARTHRA) FROM THE QUA- TERNARY OF SOUTHERN BRAZIL: SYSTEMATICS AND PALEOBIOGEOGRAPHICAL ASPECTS
}

\author{
ÉDISON V. OLIVEIRA \\ Departamento de Geologia, Centro de Tecnologia e Geociências, UFPE, Av. Acadêmico Hélio Ramos s/n, 50740-530, Recife, \\ PE, Brasil.edison.vicente@ufpe.br \\ JAMIL C. PEREIRA \\ Museu Coronel Tancredo Fernandes de Mello, Rua Barão do Rio Branco, 467, Santa Vitória do Palmar, 96230-000, RS, Brasil. \\ jamil_pereira@terra.com.br
}

\begin{abstract}
Intertropical Pleistocene taxa of dasypodids and pampatheriids are reported for the Lagoon-Barrier III System (Arroio Chuí locality) and for the Touro Passo Formation (Ponte Velha I locality), both from Rio Grande do Sul State, southern Brazil. The record of pampatheriids includes new specimens that confirm the presence of Pampatherium humboldti in the Arroio Chuí assemblage. Material previously assigned to Holmesina majus is identified as H. paulacoutoi. The record of dasypodids includes a large-sized specimen of the genus Dasypus, represented by an isolated pelvic buckler osteoderm, closely related to Dasypus (Hyperoambon) kappleri, and of Propraopus sulcatus, represented by isolated moveable and fixed osteoderms. This southernmost Brazilian record of P. sulcatus extends their distribution by about 2200 km from Lagoa Santa (Minas Gerais State, Brazil). The first record of P. sulcatus also includes specimens previously referred to as Propraopus cf. grandis from the Touro Passo Formation. Propraopus sulcatus differs from P. punctatus and $P$. grandis in having: osteoderms with wrinkled external surface, with wide and relatively deep sulci; principal figure plane, ranging from subcircular to hexagonal in fixed osteoderms; and moveable osteoderms with principal sulci forming a lageniform figure, and with four to five larger foramina distributed on the posterior half of these sulci. The late Pleistocene mammals of the coastal province and western Rio Grande do Sul were previously considered closely related to those of the Pampean region of Argentina. However, the presence of intertropical mammals in southern Brazil (Arroio Chuí locality and Touro Passo Formation) mixed with Pampean representatives, corroborates the proposal of a close paleobiogeographic relation with assemblages of northern Uruguay and Argentine Mesopotamia.
\end{abstract}

Key words: Brazil, late Pleistocene, osteoderms, Propraopus, Dasypus, Pampatherium, systematics, paleobiogeography.

RESUMO - Táxons intertropicais pleistocênicos de dasypodídeos e pampaterídeos são reportados para o Sistema Laguna-Barreira III (localidade Arroio Chuí) e para a Formação Touro Passo (localidade Ponte Velha I), ambas do Estado do Rio Grande do Sul, sul do Brasil. O registro de pampaterídeos inclui novos espécimes que confirmam a presença de Pampatherium humboldti na assembléia fóssil de Arroio Chuí. O material previamente reportado como Holmesina majus é identificado como H. paulacoutoi. O registro de dasypodídeos inclui um espécime de grande tamanho do gênero Dasypus, representado por um osteodermo pélvico isolado, intimamente relacionado a Dasypus (Hyperoambon) kappleri e de Propraopus sulcatus, representado por osteodermos isolados, de região fixa e móvel. Esse registro no extremo sul brasileiro de $P$. sulcatus estende sua distribuição em, aproximadamente, $2.200 \mathrm{~km}$ em direção ao sul, desde Lagoa Santa (MG, Brasil). O primeiro registro de $P$. sulcatus também inclui espécimes previamente referidos como Propraopus cf. grandis, da Formação Touro Passo. Propraopus sulcatus difere de P. punctatus e de $P$. grandis por possuir osteodermos com superfície externa enrugada, com sulcos amplos e relativamente profundos; figura principal plana, variando de subcircular a hexagonal em osteodermos fixos; osteodermos móveis com sulcos principais compondo uma figura lageniforme, e portando orifícios maiores (quatro a cinco) distribuídos na metade posterior desses sulcos. Mamíferos do Pleistoceno Superior da Província Costeira e oeste do Rio Grande do Sul foram previamente considerados como intimamente relacionados aos da Região Pampeana da Argentina. Contudo, a presença de mamíferos intertropicais no sul do Brasil (localidade Arroio Chuí e Formação Touro Passo), mesclada com representantes pampeanos, corrobora a proposta de uma relação paleobiogeográfica próxima entre as assembléias do Rio Grande do Sul e aquelas do Norte do Uruguai e da Mesopotâmia Argentina.

Palavras-chave: Brasil, Pleistoceno Superior, osteodermos, Propraopus, Dasypus, Pampatherium, sistemática, paleobiogeografia. 


\section{INTRODUCTION}

Pleistocene cingulates from Brazil, mainly dasypodids and pampatheriids, were first described by Peter Lund during the first half of the 19th century, on the basis of fossil material from the limestone caves of southeastern Brazil. In southern Brazil, at the end of the 19th century, armored fossil xenarthrans from Santa Vitória do Palmar, were reported by Von Ihering (1891), and sent to Argentinean paleontologist Florentino Ameghino. However, these specimens are not referred to or cited in the paleontological literature. During the 20th century several specimens were reported for distinct Quaternary localities mainly from the western and coastal region of Rio Grande do Sul State (Paula Couto, 1939, 1975; Bombin, 1976; Oliveira, 1992, 1996; Oliveira \& Pereira, 2006; Pitana \& Ribeiro, 2007).

The greatest diversity of Brazilian Pleistocene cingulates occurs in Rio Grande do Sul State. In this region, there are at least four taxa of Pampatheriidae: Holmesina majus (Lund, 1842), H. paulacoutoi (Cartelle \& Bohórquez, 1985), Pampatherium typum Gervais \& Ameghino, 1880, and $P$. humboldti (Lund, 1839); four of Dasypodidae: Propraopus cf. $P$. grandis, Ameghino, 1881, P. punctatus (Lund, 1840), $P$. sulcatus (Lund, 1842) and Dasypus Linnaeus, 1758); and at least six of Glyptodontidae: Glyptodon clavipes Owen, 1839, G. reticulatus Owen, 1845, Panochthus Burmeister, 1866, Doedicurus Burmeister, 1874, Neothoracophorus aff. elevatus Nodot, 1857 and Neuryurus Ameghino, 1889 (Bombin, 1976; Oliveira, 1996; Pitana \& Ribeiro, 2007; Kerber \& Oliveira, 2008a).

In recent years, the increased study of late Pleistocene mammals from southern Brazil, northern Uruguay and Argentinean Mesopotamia (Entre Rios and Corrientes areas) has enabled the development of alternative hypotheses on the paleobiogeography of these areas during the Pleistocene (see Ubilla, 1985; Ubilla et al., 2004; Oliveira, 1996, 1999; Scillato-Yané et al., 1998; Carlini et al., 2003, 2008). The recent discovery of new materials of pampatheriids and dasypodids and the revision of previously reported Propraopus, allowed us to test one of these hypotheses, particularly those involving the existence of mixed faunas in western and southernmost Rio Grande do Sul.
In this paper, new material of poorly known taxa of armored xenarthrans for the southernmost Brazil is described, and the species of Propraopus occurring in Brazil are characterized. Furthermore, considerations on the paleobiogeography of the fossil localities located in the western and southernmost parts of Rio Grande do Sul State are discussed.

\section{GEOGRAPHIC AND STRATIGRAPHIC SETTING}

The Arroio Chuí locality is situated in the municipality of Santa Vitória do Palmar, in southernmost Rio Grande do Sul and is exposed on the banks of Arroio Chuí (Figure 1). The outcrops in the Arroio Chuí belong to the Lagoon-Barrier III System (Santa Vitória Formation). The age of the paleofauna is correlated to the Lujanian Stage/Age of Buenos Aires Province (Oliveira, 1999), according to the guide fossil Equus neogeus (Cione \& Tonni, 1999).

Touro Passo Formation fossils were recovered in the Ponte Velha I locality (see Kerber \& Oliveira, 2008b,c), situated in the vicinity of the disabled railroad (2939' $\left.56^{\prime \prime} \mathrm{S}, 56^{\circ} 52^{\prime} 14^{\prime \prime} \mathrm{W}\right)$, municipality of Uruguaiana, western Rio Grande do Sul (Figure 1). The mammalian fauna of the Touro Passo Formation is also regarded as Lujanian in age, latest Pleistocene (Oliveira, 1999; Oliveira \& Kerber, 2009).

\section{MATERIAL AND METHODS}

The nomenclature (Figure 2) used for osteoderms (= scutes, plates) follow the papers of Oliveira \& Bergqvist (1998) and Vizcaíno et al. (2003), which identified on the external surface (dorsal view) the presence of peripheral figures, separated by radial sulci; the principal figure (= central figure) is situated posteriorly in the moveable osteoderms or medially to the anterolateral peripheral figures in the fixed osteoderms; the sulcus that delimits the principal figure is identified as the principal sulcus, and is variable, where it is parallel (or inverted V-shaped) in the moveable osteoderms and circular, polygonal or inverted U-shaped in fixed osteoderms. In pampatheres, the principal figure is subrectangular (or polygonal) and occupies the most of the ornamented area; the sulci in this case border the central elevation (central keel). The principal figure sometimes also
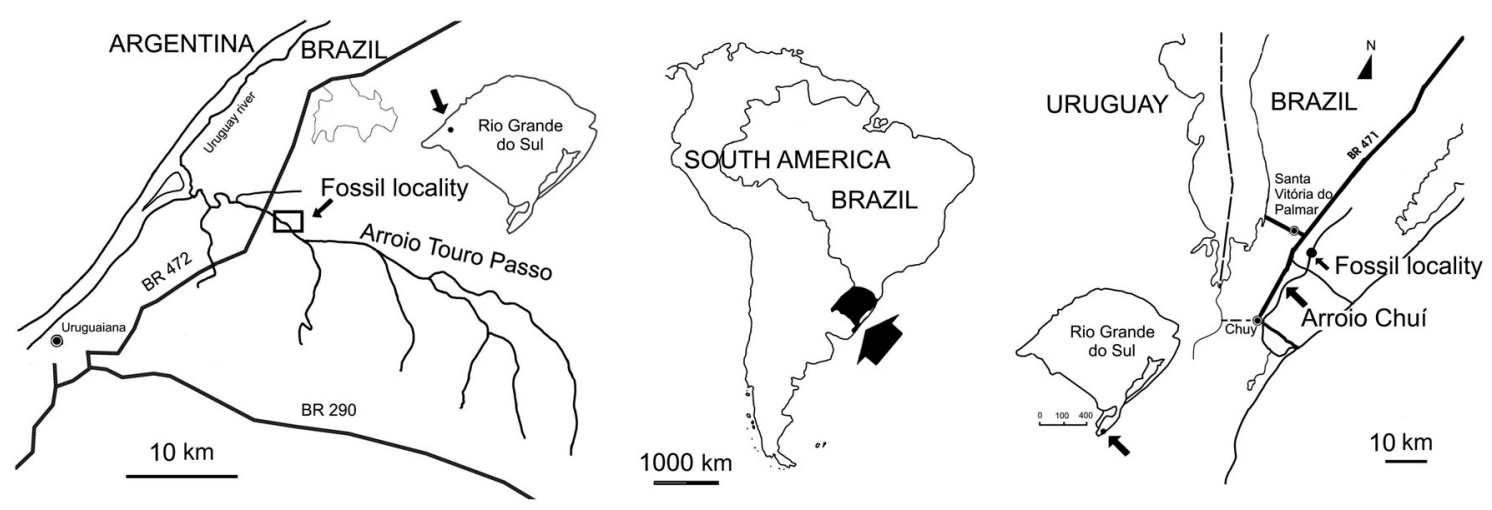

Figure 1. Location map of the collection sites in the Touro Passo Formation and Arroio Chuí, in Rio Grande do Sul State, Brazil. 


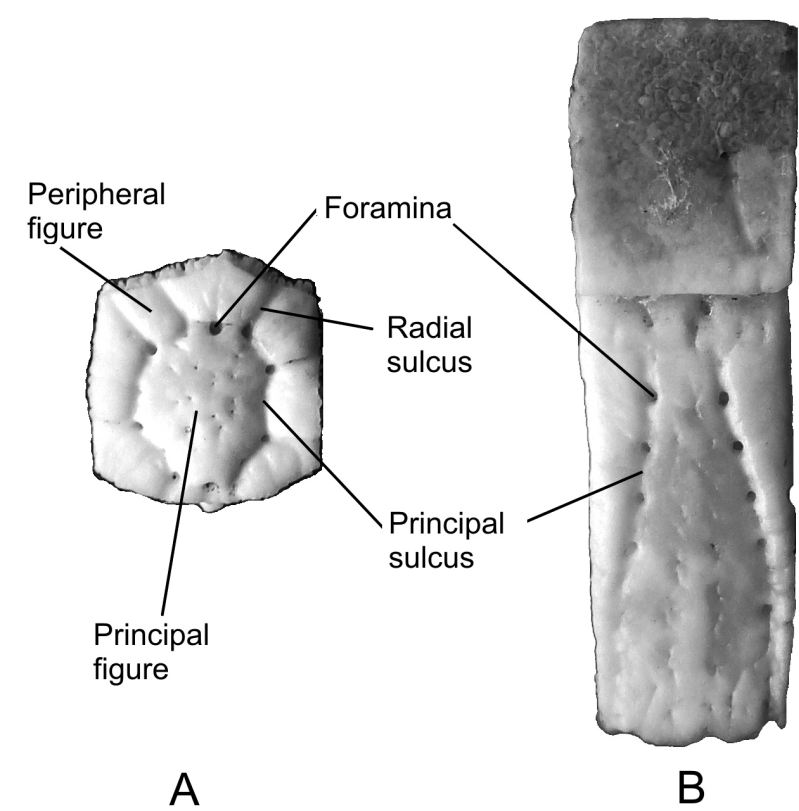

Figure 2. Terminology used for osteoderm morphology (dorsal view) in Dasypus hybridus. A, fixed osteoderm; B, moveable osteoderm.

bears small orifices in its central region, and fine and short sulci. Foramina (hair follicles) of greater size are located on the principal sulcus and also on the radial sulci.

We follow Cartelle (1999) by identifying the late Pleistocene mammals from southeastern and northeastern Brazil as intertropical, although some taxa such as Holmesina, Propraopus and Eremotherium have a tropical to temperate distribution. Other authors (Ubilla et al., 2004) regard the tropical and intertropical mammals as Brazilian or "brasilic" fauna. The measurements presented in the text are in $\mathrm{mm}$.

Institutional abbreviations. EPM-PV, Emgidio Pinto Martino Collection, Museu Coronel Tancredo Fernandes de Mello, Santa Vitória do Palmar, RS, Brazil; MCPU-PV, Museu de Ciências, PUCRS Uruguaiana, RS, Brazil; MNRJ, Museu Nacional, Rio de Janeiro, RJ, Brazil.

Anatomical abbreviations. L, maximum anteroposterior length; $\mathbf{W}$, maximum width; $\mathbf{T}$, thickness.

\section{SYSTEMATIC PALEONTOLOGY}

\author{
XENARTHRA(Cope) \\ CINGULATA(Illiger) \\ DASYPODA (Quenstedt) Hoernes \\ DASYPODIDAE (Gray) \\ Propraopus aff. P. sulcatus (Lund, 1842)
}

(Figures 3A-C, 4A-B)

Referred specimens. EPM-PV 0442, pelvic buckler osteoderm, EPM-PV 0443, MCPU-PV 024, 135, moveable osteoderms.

Measurements. EPM-PV 0442: W 16.4; L 16.0; T 6.4.; EPMPV 0443: W 13.9; T 6.7; MCPU-PV 024 W 13.4 (on ornamented region); $\mathrm{W}$ (on articular surface) 11.9; $\mathrm{T}$ (on ornamented region) 4.3; $\mathrm{T}$ (on articular surface) 6.7; MCPU-PV $135 \mathrm{~W}$ (on ornamented region) $13.8 ; \mathrm{W}$ (on articular surface) $13.5 ; \mathrm{T}$ (on ornamented region) 4.4; $\mathrm{T}$ (on articular surface) 6.8.

Description. EPM-PV 0443 exhibits the ornamented surface similar to that of the fixed osteoderms, slightly sculptured on all surfaces by several fine, short and sinuous sulci. The two sulci that delimit the principal figure are wide and shallow. Anteriorly, where both sulci converge, the distance between these sulci is slightly larger than that of the peripheral figures. The principal sulci are slightly curved proximally, so that the principal figure is lageniform in outline.

The specimen MCPU-PV 024 shows a size equivalent to that of the osteoderms illustrated by Winge (1915: plate V), being only slightly smaller. On the ornamented area, the external surface is sculptured by small semilunar protuberances, so that the surface is clearly wrinkled. The foramina on each principal sulcus are four or five in number and are restricted to the posterior half of these sulci. On the medial region of the principal figure is a narrow, elongated and slightly elevated longitudinal keel.

The external surface of the EPM-PV 0442 is wrinkled, similar to the described for the moveable osteoderm MCPU-PV 025. The foramina on the principal sulcus are three in number, and two of them are not situated at the intersection of the radial and the principal sulcus. The principal figure is planar and subcircular to hexagonal in outline. The principal and radial sulci are wide and relatively deep. The articulation surfaces are strongly denticulate, with numerous sharp pointed bones (Figure 3C).

Discussion. Except in moveable osteoderms, the EPM-PV 0442 resembles the external structure of the glyptodontid Pachyarmatherium Downing \& White, 1995, from late Pliocene to Pleistocene of North America and late Pleistocene of South America, including Venezuela, and the Brazilian states of Rio Grande do Norte and Rio Grande do Sul (Rincón, 2003; Porpino et al., 2008; Bostelmann et al., 2008). A detailed comparison reveals that the osteoderms of Pachyarmatherium are much thicker than EPM-PV 0442 and the foramina on the principal sulcus are situated just at the intersection of the radial and the principal sulci. Below, we justify the identification of the EPM-PV 0442 as Propraopus aff. P. sulcatus.

Peter W. Lund described the remains of two extinct species of armadillos, which were named Dasypus punctatus and $D$. sulcatus. Later, Winge (1915) described and illustrated the type material of these species and preserved Lund's generic original names. Hoffstetter (1952) suggests that the armadillos from the limestone caves of Minas Gerais, Brazil, should be identified as Propraopus, which was proposed by Ameghino (1881). In this manner, the Brazilian species were recognized as $P$. sulcatus and P. punctatus. Four (or five, see below) species of Propraopus are reported in the current literature and are based on the studies of Hoffstetter (1952) and Paula Couto $(1973,1979)$. According to these authors, there is no morphological difference between $P$. grandis from Argentina, P. magnus (Wolf, 1875) from Equator, and $P$. sulcatus from Brazil. According to Paula Couto (1982), the only valid species is $P$. punctatus. However, in this work we consider that $P$. 
sulcatus and $P$. grandis constitute valid taxa (see below). Another current species that could belong to Propraopus is Dasypus bellus (Simpson, 1930), from North America (Hoffstetter, 1958; see also Rincón et al., 2008). The osteoderms of $D$. bellus have potential synapomorphies of the genus Propraopus, such as: the sulci that delimit the principal figure on moveable osteoderms are subparallel anteriorly (V-shaped on Dasypus); the principal figure on fixed osteoderms has a hexagonal to circular outline, with foramina not situated on the confluence between the radial sulci and the principal sulcus.

As seen above, Propraopus sulcatus was originally described for Lagoa Santa, Minas Gerais State (southeastern Brazil). This species, only recorded for this locality (Winge, 1915), was recently registered in the late Pleistocene of western Venezuela (Rincón et al., 2008). The present record of Propraopus aff. P. sulcatus for southern Brazil extends its geographical distribution by about $2200 \mathrm{~km}$ (Figure 8).

Potential synapomorphies for Propraopus sulcatus include: surface of fixed osteoderms wrinkled with small semilunar elevations; three large foramina, and not situated on the confluence between the radial and the principal sulcus; the principal figure on fixed osteoderms is subcircular to hexagonal in outline; articulation borders are strongly denticulate; principal figure is delimited by two subparallel sulci, moderately deep, and lageniform in outline; four to five foramina on the principal sulci are distributed on the posterior half of the ornamented area.

As seen above, the species closely related to Propraopus sulcatus are $P$. punctatus and $P$. grandis. The first one was described for the late Pleistocene of Minas Gerais, Rio de Janeiro and São Paulo (Paula Couto, 1982), and reported in one faunal list for the Touro Passo Formation, western Rio Grande do Sul (Bombin, 1976). However, this last record was not confirmed by later studies (Paula Couto, 1979; Oliveira, 1996; Pitana \& Ribeiro, 2007). Propraopus punctatus (Figure 5A) differs from $P$. sulcatus in having a smaller size; number of foramina on each principal sulcus, ranging from eleven to sixteen, in both moveable and fixed osteoderms; diameter of foramina in moveable osteoderms larger than the principal sulcus; the principal sulci of moveable osteoderms are deep and, comparatively, are more laterally displaced than in $P$. grandis and $P$. sulcatus. Thus, considering these characters we agree that $P$. punctatus is a valid species.

Propraopus grandis (Figure 5C) was originally described for Argentina (Ameghino, 1881), and later reported for Uruguay, Paraguay (?), Bolivia (?) and Rio Grande do Sul. On the basis of Ameghino's description, it is clearly larger than $P$. sulcatus (Ameghino, 1889), where mention is made of moveable osteoderms of about $80 \mathrm{~mm}$ in length and 14 to 15 $\mathrm{mm}$ wide. Thus, the osteoderms in $P$. grandis are very long and narrow. A nearly complete osteoderm of $P$. sulcatus figured by Winge (1915) is about $58 \mathrm{~mm}$ in length, a size comparable to that of the osteoderms here referred to as $P$. aff. P. sulcatus (Figure 4). Propraopus grandis differs from $P$. sulcatus in having the ornamented area with principal figure nearly smooth, only slightly ornamented by fine sulci; the principal sulci on the moveable osteoderms are shallow and the larger foramina are distributed on the entire extension of the sulci; anteriorly, where the two longitudinal principal sulci converge, the diameter transverse is equal to width of the peripheral figures, with the exception of the osteoderms from the lateral area of the carapace, where the sulci compose an inverted V-shaped figure. The fixed osteoderms have the principal figure ranging from oval to subcircular in outline, which is strongly convex distally; two or three large foramina on osteoderms from the scapular region are present on the principal sulcus, and are not situated on the intersection between principal and the radial sulcus. The diameter of the foramina on scapular osteoderms is larger than the width of the principal sulcus, and in the pelvic osteoderms this diameter appears to be smaller.

\section{Dasypus sp. \\ (Figures 3D-E)}

Referred specimens. EPM-PV 0444, scapular osteoderm. Measurements. W 9.7; L 11.6; T 4.0.

Description. The osteoderm is sub-rectangular in outline, with the posterior border slightly curved posteriorly. The articulation borders are nearly smooth, very poor denticulate. The peripheral figures are five in number and more convex in relation to the principal figure; these figures are separated from the principal figure by a sulcus relatively wide and deep. The principal figure is flat and bears small orifices and short grooves, which are parallel (three on the left side and four on the right side). The grooves are transverse and irradiate from the small orifices. The foramina on the principal sulcus are situated at the corner of the peripheral figures and not at the intersection with the radial sulci.

Discussion. In the Quaternary of northern southern and southeastern Brazil the family Dasypodidae is represented by five taxa of armadillos, distributed in the genera Propraopus, Dasypus, Cabassous McMurtrie, 1831, Euphractus Wagler, 1830 and Tolypeutes Illiger, 1811, recovered from Pleistocene deposits of Minas Gerais, São Paulo, Rio de Janeiro, Acre, Rio Grande do Sul, Piauí, and Bahia (Ameghino, 1907; Paula Couto, 1973, 1979, 1983; Oliveira, 1996; Faure et al., 1999; Porpino, 1999; Porpino et al., 2004).

The first unequivocal record of Dasypus for the Pleistocene of South America was reported by Vizcaíno et al. (1995), on the basis of the description of Dasypus aff. novemcinctus, from the Sopas Formation, northern Uruguay. Recently Dasypus sabanicola was reported for the Pleistocene of Venezuela (Rincón et al., 2008). According to Vizcaíno et al. (1995), previous citations of Dasypus for the Pleistocene of South America are misleading and without precise stratigraphic location.

On the basis of osteoderms, Dasypus differs from Propraopus in having fixed osteoderms with the principal figure subcircular or inverted U-shaped in outline; the foramina on the principal sulcus are placed at the intersection of the principal sulcus and the radial sulci; and the moveable osteoderms have two principal sulci, which is V-shaped in 


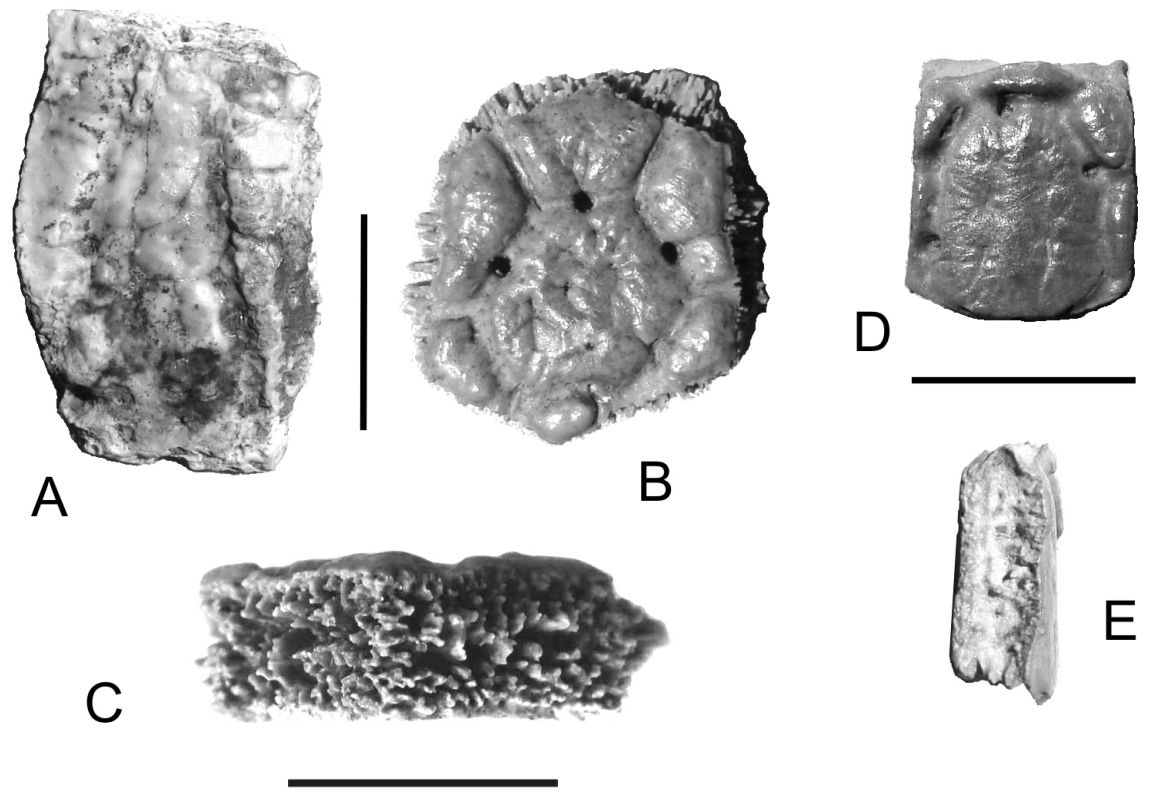

Figure 3. Osteoderms of Dasypodidae. A-C, Propraopus aff. P. sulcatus: A, EPM 0443, moveable osteoderm, dorsal view; B, EPM 0442, fixed osteoderm, dorsal view; C, EPM 0442, lateral view. D-E, Dasypus sp.: D, EPM 0444, dorsal view; E, lateral view. Scale bars = $1 \mathrm{~cm}$.

outline (sub-parallel in Propraopus). Furthermore, the articulation borders in Dasypus are almost smooth.

EPM-PV 0444 is clearly more robust when compared to the homologous osteoderm of the living Dasypus novemcinctus, D. hybridus, D. septemcinctus, and $D$. sabanicola, where it is comparable in size to that of $D$. kappleri. Wetzel \& Mondolfi (1979) recognizes within Dasypus the subgenera Dasypus, Cryptophractus and Hyperoambon, the last subgenus being proposed for Dasypus kappleri. The external surface smooth, slightly sculptured by fine sulci and parallel small orifices, of EPM-PV 0444 is shared with $D$. hybridus, $D$. novemcinctus and $D$. kappleri. However, in D. novemcinctus and in D. hybridus, the foramina on the principal sulcus are situated just at the intersection between the principal sulcus and the radial sulci, a character that is not observed in EPM-PV 0444, where the foramina occur close to the internal corner of the peripheral figures. In D. (Hyperoambon) kappleri, the foramina are in greater number and some ones are situated just as in EPM-PV 0444. In most plesiomorphic dasypodids such as the Paleogene Astegotheriini, the foramina are scarcely situated at the intersection of the principal and radial sulci. The presence of this character on EPM-PV 0444 suggests a more plesiomorphic degree in relation to the living species of Dasypus.

Ameghino (1891) described Dasypus neogaeus for Entre Rios, in Argentina. However, the type specimen is supposedly older and represented by one moveable osteoderm (ScillatoYané, 1980), while the material described here is late Pleistocene and consists of a fixed osteoderm.

Of all the living armadillos of the genus Dasypus, EPMPV 0444 appears to be more closely related to Dasypus (Hyperoambon) kappleri. This species is distributed on east of the Andes in Colombia, south of Rio Orinoco in Venezuela,
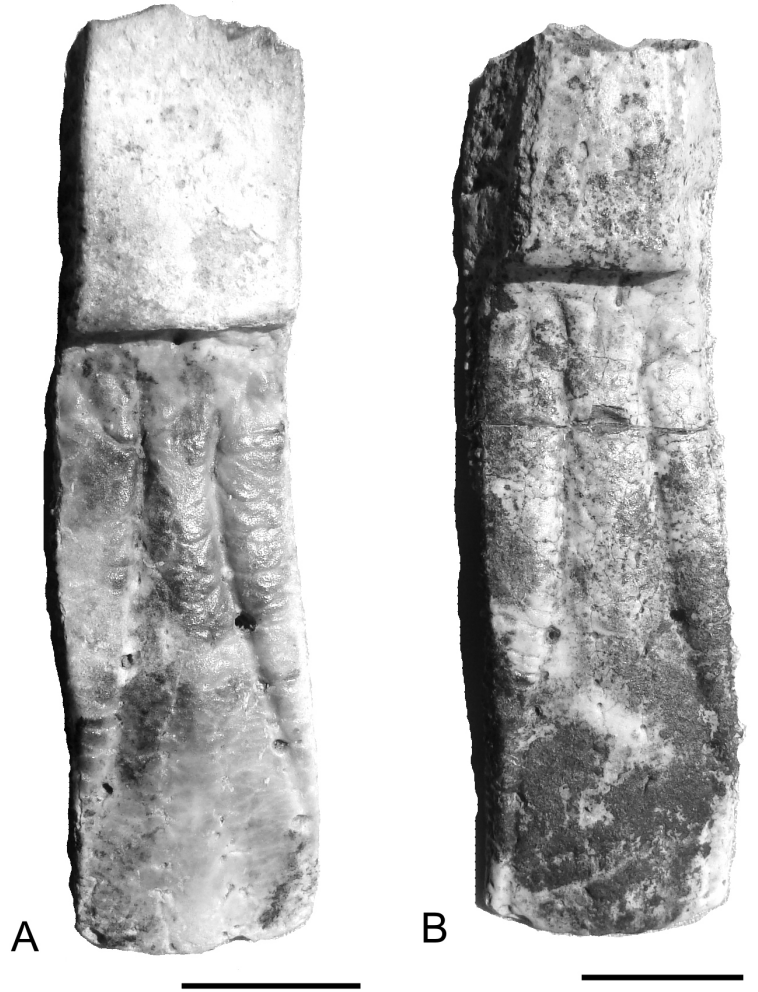

Figure 4. Moveable osteoderms of Propraopus sulcatus: A, MCPUPV 024, dorsal view; B, MCPU-PV 135, dorsal view. Scale bars $=1$ $\mathrm{cm}$.

and in Guyana, Surinam, French Guiana, and the Amazon basin of Brazil, Ecuador, Peru and northeastern Bolivia (Wetzel \& Mondolfi, 1979). Because of the scarcity of the material described here, represented by only one osteoderm, we regard it as Dasypus sp. 


\section{GLYPTODONTIAAmeghino \\ PAMPATHERIIDAE Paula Couto \\ Pampatherium humboldti (Lund, 1839) \\ (Figures 6A-D)}

Referred specimens. EPM-PV 0445, 0446, fixed osteoderms; EPM 407, marginal osteoderm.

Measurements. EPM-PV 0445: L 37.4; W 27.5; T 8.4; EPMPV 0446 L 51.1; W 28.5; T 9.0.

Description. EPM-PV 0446 (Figures 6A,B) has the external surface very punctuated by small pits and is almost even; the marginal area is very narrow, mainly on the lateral and posterior regions; there is no large difference between the marginal area and the principal figure; numerous foramina are present on the anterior region, but are scarce on marginal area; the principal figure is wide (rectangular) and very low; the longitudinal elevation is elongated and delimited laterally by two very shallow sulci. The specimen EPM-PV 0405 (Figure 6C) differs from EPM-PV 0446 in having a smaller size, being slender, and showing a principal figure better defined and sub-oval in outline; the furrows that delimit the principal figure show larger orifices than on the central region of the principal figure. The osteoderm from the margin of the imbricating area (Figure 6D) has an ornamented surface similar to that of the fixed osteoderms; the principal figure is subrectangular and not delimited posteriorly by the marginal area; in general, this osteoderm is very similar to that figured by Winge (1915: figure 11). All the articulation borders in Pampatherium humboldti show two lines of cancellous (trabecular) bone which are separated by a deep and large sulcus (Figure 6B).

Discussion. In Brazil, the Quaternary Pampatheriidae are represented by the genera Pampatherium and Holmesina Simpson, 1930, known originally from the limestone caves
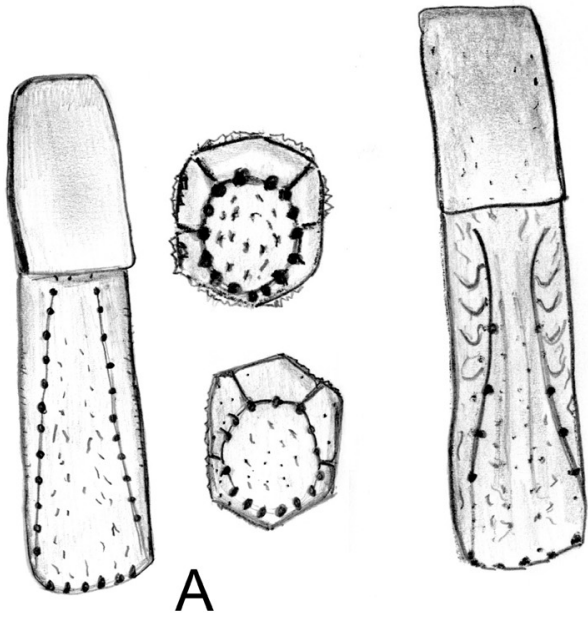
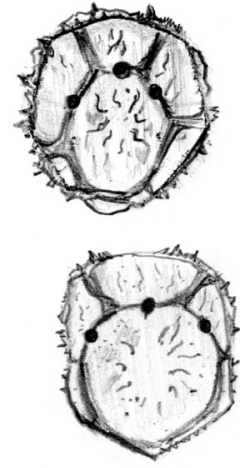

$\mathrm{B}$

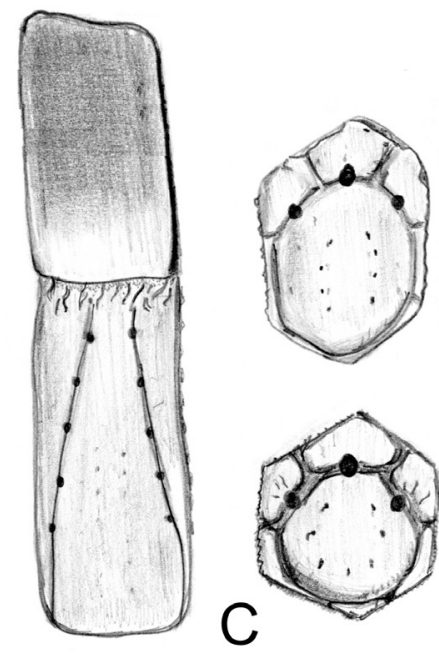

Figure 5. Fixed and moveable osteoderms of the species of Propraopus Ameghino, 1881 reported for Brazil. A, Propraopus punctatus; B, P. sulcatus; C, P. grandis.
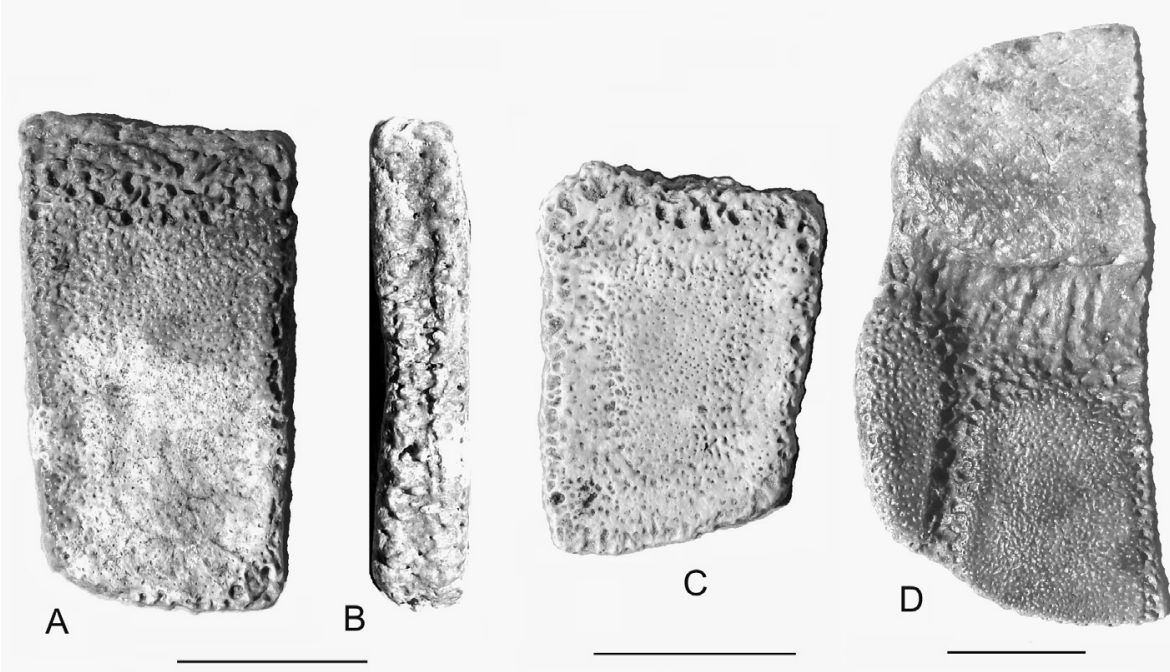

Figure 6. Osteoderms of Pampatherium humboldti: A, EPM-PV 0446, fixed osteoderm, lateral view; B, EPM-PV 0446, fixed osteoderm, lateral view; C, EPM-PV 0445, fixed osteoderm, dorsal view; D. EPM-PV 0407, marginal osteoderm, dorsal view. Scale bars $=2 \mathrm{~cm}$. 
of Lagoa Santa (Lund, 1840; Winge, 1915) and later referred for the states of Rio Grande do Sul, Santa Catarina, Bahia, Ceará and Rio Grande do Norte (Paula Couto, 1980; Cartelle \& Bohórquez, 1985; Edmund, 1996; Oliveira, 1996; Porpino et al., 2004). Currently, the Rio Grande do Sul State (RS) has the greatest number of taxa in comparison with other Brazilian regions, with four species recorded. For the Touro Passo Formation, in the western part of this state, Paula Couto (1975) and Bombin (1976) have reported, but not illustrated or described, osteoderms of Pampatherium humboldti. For this same geological unit, Paula Couto (1975), Oliveira (1996), Oliveira et al. (2003) and Kerber \& Oliveira (2008c) reported remains of Pampatherium typum (Gervais \& Ameghino, 1880). Edmund (1996) reported osteoderms of Holmesina majus for Rio Grande do Sul, without however referring to the locality from which the material was recovered (but see below). Holmesina paulacoutoi (Cartelle \& Bohórquez, 1985) was identified for the Arroio Chuí, municipality of Santa Vitória do Palmar, through the osteoderms deposited at Museu Nacional, Rio de Janeiro and Fundação Zoobotânica do Rio Grande Sul, Porto Alegre (Cartelle et al., 1989; Oliveira, 1996). Later, Oliveira et al. (2003) identified new osteoderms of Holmesina cf. H. paulacoutoi and of Pampatherium typum for the Arroio Chuí and Touro Passo Formation.

Pampatherium humboldti constitutes the type species of the family Pampatheriidae, and besides, it has been described for several Brazilian states and also reported for northern Uruguay (Ubilla et al., 2004) and northwest Venezuela (Rincón et al., 2008). Scillato-Yané et al. (2005) characterized the external surface of the osteoderms as almost even for $P$. typum and slightly sculpted in $P$. humboldti; the osteoderms of $P$. humboldti are somewhat more rugose than those of $P$. typum and have a defined principal figure (absent in P. typum). In P. humboldti, the posterior marginal area of the buckler osteoderms is narrow or absent (Edmund, 1996). We agree with these observations and identified the material described herein as Pampatherium humboldti; furthermore, the thickness of the material described herein exceeds the mean of $P$. typum (see Edmund, 1996), which is regarded as the smallest and least robust of the Quaternary Pampatheriidae of South America. We examined osteoderms regarded as $P$. typum from the late Pleistocene of Rio Grande do Sul and noted in this species the absence of the sculpted area on principal figure. The material described as $P$. typum by Kerber \& Oliveira (2008) is represented by small and slender osteoderms but with external surface slightly more rugose than in typical P. typum.

Based on a lot of 17 osteoderms (MNRJ 3538-V), Edmund (1996) identified Pampatherim humboldti from Santa Vitória do Palmar, Rio Grande do Sul State. After examining this lot, we identified it as Pampatherium typum, because of being slender and because there are no traces of ornamentation on the principal figure.
Holmesina paulacoutoi (Cartelle \& Bohórquez, 1985) (Figures 7A-E)

Referred specimens. MNRJ 3538-V(a), complete fixed osteoderm; MNRJ 3538-V(b), incomplete distal moveable osteoderm; MNRJ 3538(c-e), two complete and one incomplete fixed osteoderm.

Measurements. MNRJ 3538-V(a): L 55,3; W 48,5; T 14.3. Discussion. The lot MNRJ 3538-V from Santa Vitória do Palmar, is composed of five osteoderms, separated in MNRJ 3538-V(c-e), which are very probably from the seashore sediments and MNRJ 3538(a-b) herein assumed as recovered from the latest Pleistocene sediments of the Arroio Chuí. Edmund (1996) identified these osteoderms as Holmesina majus, and later, Oliveira (1996) regarded these specimens as Holmesina paulacoutoi. In the present paper, we also regard these osteoderms as H. paulacoutoi. MNRJ 3538(a) (Figures 7A-C) is large and thick, with external surface very punctuate and rugose. Although incomplete, MNRJ 3538(b) (Figures 7D, E) has the external surface rugose and the marginal area relatively wide. These specimens were compared with a lot of osteoderms identified by Edmund (1996) as Holmesina majus from Ceará (MNRJ 4294-V ex 2679 and 4275 ex 2767-V), northeastern Brazil. In the Ceará specimens, the osteoderms are slender, the external surface is less rugose and the marginal area is wider.

\section{PALEOBIOGEOGRAPHY OF THE TOURO PAS- SO FORMATION AND ARROIO CHUÍ LOCALITY}

For a long time, the late Pleistocene faunas of the Quaternary of Rio Grande do Sul were interpreted as being exclusively related to the Pampean fauna (Paula Couto, 1975:107), or in the specific case of the Arroio Chuí locality, as being identical to that of the Pampean region (Paula Couto, 1980:530). The study of the mammalian paleofauna from the Arroio Chuí, suggests an alternative scenario compared to that previously proposed by Paula Couto. The analysis of this fauna showed the presence of intertropical taxa, as illustrated by Propraopus aff. sulcatus, Holmesina paulacoutoi, Pampatherium humboldti, Hydrochoerus hydrochaeris, Catagonus (= Brasiliochoerus) stenocephalus, Tapirus terrestris, Stegomastodon waringi, Protocyon troglodytes, Catonyx sp., and Tayassu sp. (see Oliveira et al., 2005). Interestingly, all these taxa are absent in the Guerrero Member of the Luján Formation, from the Pampean region, Buenos Aires Province, Argentina. Another interesting aspect is that besides these intertropical taxa, the fauna of Arroio Chuí includes elements of the Pampean taxa of wide distribution in South America, such as Glyptodon clavipes and Toxodon cf. T. platensis, and to a lesser degree taxa of austral distribution such as Doedicurus, Mylodon darwini 
and Macrauchenia patachonica. Remarkably, Mylodon darwini has been reported for the El Palmar Formation, Entre Rios Province, in Argentina (Brandoni \& Ferrero, 2009) and Macrauchenia patachonica for the Sanga da Cruz locality, in western Rio Grande do Sul State (Oliveira, 1992; Lessa \& Oliveira, 1996).

The Touro Passo Formation, in western Rio Grande do Sul, also includes mammals with tropical to intertropical distribution, including Holmesina cf. paulacoutoi, Hydrochoerus hydrochaeris, Stegomastodon waringi, Tapirus sp., Tayassu sp. and Propraopus aff. P. sulcatus. Except for the remains of Lagoa Santa, the Touro Passo Formation is the first late Pleistocene lithostratigraphic unit to record both Propraopus grandis (Pitana \& Ribeiro, 2007) and $P$. aff. sulcatus. In this respect, the discovery of $P$. aff. sulcatus in two late Pleistocene localities of Rio Grande do Sul makes it necessary to revise all the material previously regarded as Propraopus cf. P. grandis from this state.

In other Pleistocene localities from Rio Grande do Sul, such as the Passo do Megatério, municipality of Caçapava do Sul, there is the singular association of the intertropical Eremotherium and the austral taxon Megatherium, in the same deposit, at the Arroio Pessegueiro (Oliveira et al., 2002).

As seen above, the record of tropical to intertropical mammals with Pampean taxa reveals the existence of mixed mammalian faunas, similar to that verified for faunas of the late Quaternary of Argentine Mesopotamia (Scillato-Yané et al., 1998; Carlini et al., 2003, 2008; Gasparini \& Zurita, 2005; Zurita et al., 2005) and northern Uruguay (Ubilla et al., 2004). In this context, the area composed today of southernmost Brazil, northern Uruguay, and Argentine Mesopotamia (Figure 8), could have been a zone of contact between paleobiogeographic regions or even a particular biogeographic region.

Taking into account exclusively the Arroio Chuí mammal association, three possible explanations could be raised: (i) the fauna is exclusively related to the Lagoa Santa (or southeastern Brazil); (ii) the fauna shows an artificial association of taxa as a result of time-averaging, possibly in the last 120,000 years, where climatic fluctuations

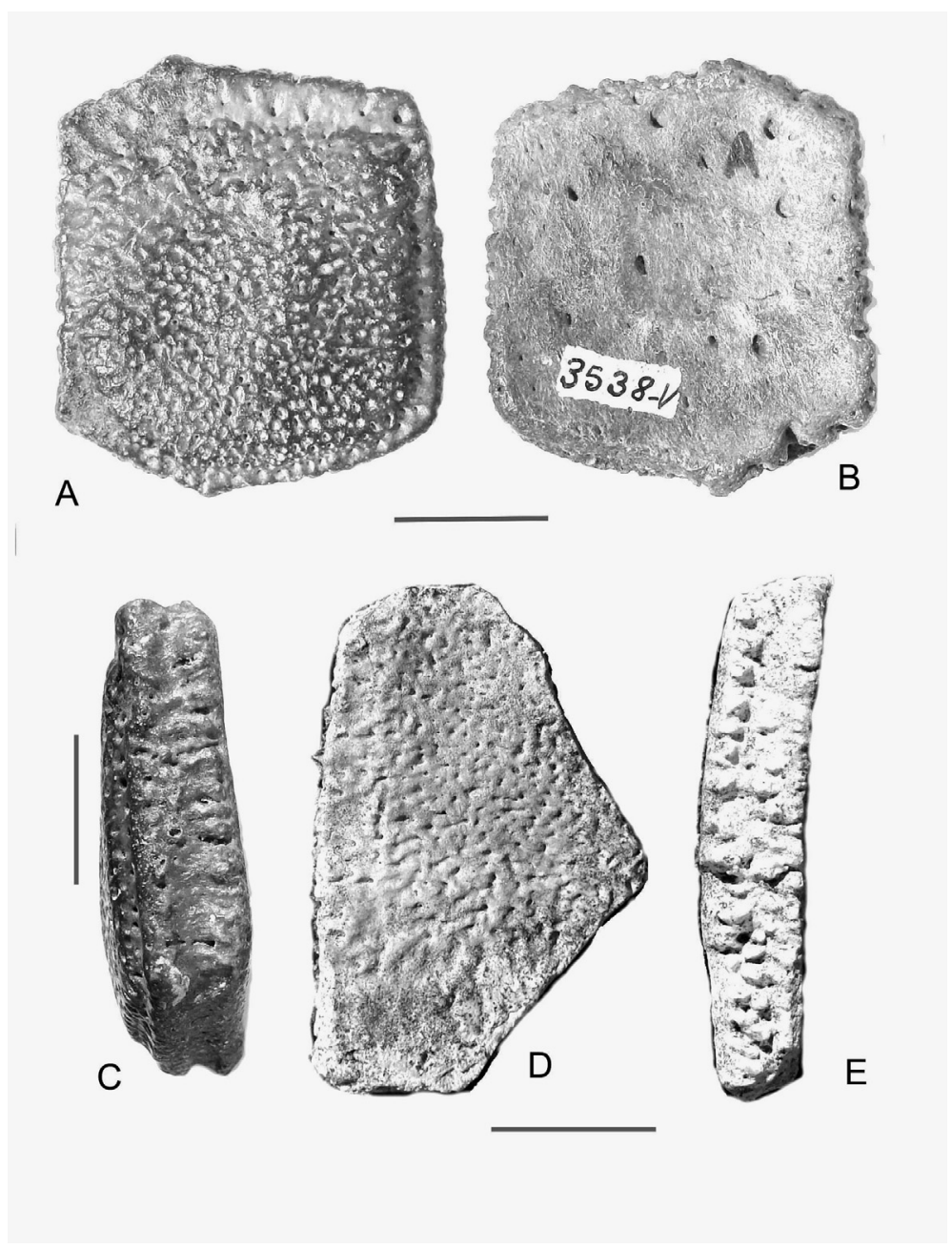

Figure 7. Osteoderms of Holmesina paulacoutoi: A, MNRJ 3538(a), fixed osteoderm, dorsal view; B, MNRJ 3538(a), fixed osteoderm, internal view; C, MNRJ 3538(a), fixed osteoderm, lateral view; D, MNRJ 3538(b), moveable osteoderm, dorsal view; E, MNRJ 3538(b), moveable osteoderm, lateral view. Scale bars $=2 \mathrm{~cm}$. 


\section{REFERENCES}

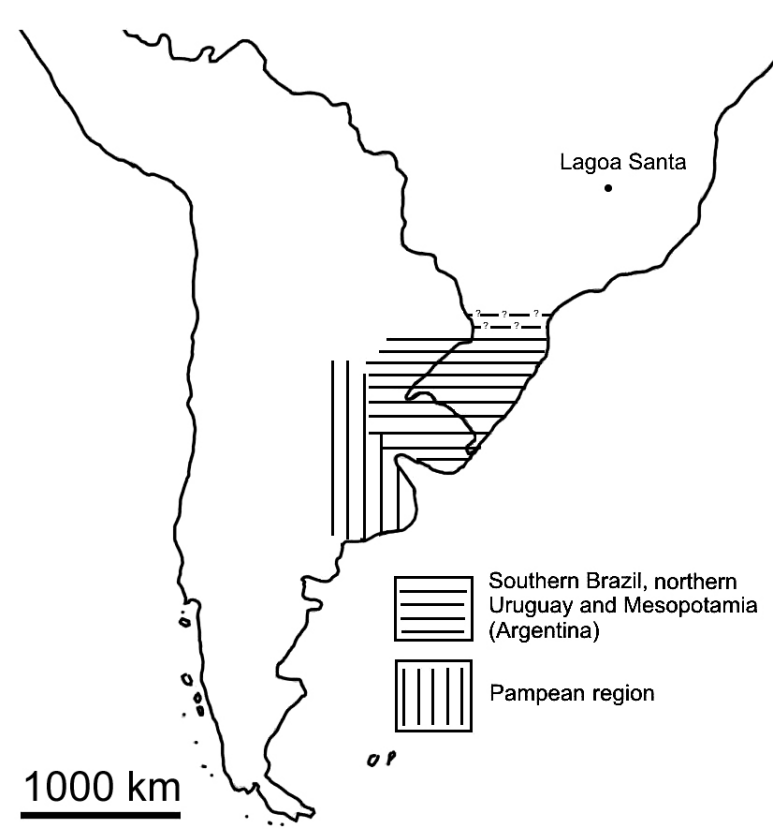

Figura 8. Paleobiogeographic map of the late Pleistocene of southeastern South America. The Pampean region is according to Carlini et al. (2003).

between colder (stadial) and warmer (interstadial) conditions during the glacial and interglacial epochs are known; and (iii) the fauna is mixed, with Pampean and intertropical taxa occurring in the same assemblages. An assessment of recent paleontological evidence suggests that the most probable hypothesis is the last ones taking into account the discovery of intertropical elements in the Arroio Chuí locality and taphonomical aspects related to the preservation of vertebrate bones from this locality (Lopes et al., 2001; Oliveira et al., 2005). Most fragmentary bones exhibit minimal signals of weathering and fresh fractures. Most material suggests that actual fluvial erosion is responsible for the disarticulation or fractures of bones. The study of Microcavia (Ubilla et al., 2007) cranial and postcranial elements, clearly demonstrates that the current fluvial erosion caused the breakage pattern observed in the material and that the remaining parts of the skeleton were removed by flooding.

Regarding the Touro Passo Formation, in which taphonomic studies suggest the effect of time-averaging for the Ponte Velha I locality (Kerber, 2008), the fauna could be an artificial association of taxa, possibly of the last 40,000 years.

\section{ACKNOWLEDGMENTS}

We are indebted to D. Henriques who allowed us to access the collections of MNRJ. Appropriate and helpful comments of the reviewers A. A. Carlini and Martin Ubilla improved this paper.
Ameghino, F. 1881. La antigüedad del hombre en el Plata. ParísBuenos Aires, Masson-Igon Hermanos, vol. 1-2, 557 p.

Ameghino, F. 1889. Contribución al conocimiento de los mamíferos fósiles de la República Argentina. Actas de la Academia Nacional de Ciencias de Córdoba, 6:1-1027.

Ameghino, F. 1891. Caracteres diagnósticos de cincuenta espécies nuevas de mamíferos fósiles argentinos. Revista Argentina de Historia Natural, 1:129-167.

Ameghino, F. 1907. Notas sobre una pequeña colección de huesos de mamíferos procedentes de las grutas calcárias de Iporanga, en el Estado de São Paulo, Brasil. Revista do Museu Paulista, 3(7):59-124.

Bombin, M. 1976. Modelo paleoecológico evolutivo para o Neoquaternário da região da Campanha-Oeste do Rio Grande do Sul (Brasil). A Formação Touro Passo, seu conteúdo fossilífero e a pedogênese pós-deposicional. Comunicações do Museu de Ciências da PUCRS, 15:1-90.

Bostelman, E.; Rinderknecht, A. \& Pereira, J. 2008. Primeros registros de Glyptatelinae cuaternarios (Mammalia, Xenarthra), para el cono sur de sudamérica. In: CONGRESO LATINOAMERICANO DE PALEONTOLOGÍA DE VERTEBRADOS, 3, 1980. Resúmenes, Neuquén, p. 29.

Brandoni, D. \& Ferrero, B.S. 2009. Consideraciones biogeográficas, paleoambientales y paleobiológicos de Mylodon darwini Owen (Xenarthra: Mylodontidae) en el Pleistoceno tardío de Entre Ríos, Argentina. In: XXIV JORNADAS ARGENTINAS DE PALEONTOLOGÍA DE VERTEBRADOS, 24, 2009. Resúmenes, San Rafael.

Burmeister, H. 1866. Einige Bemerkungen über die im Museum zu Buenos Aires befindlichen Glyptodonarten. Zeitschrift für die gesammten Naturwissenschaften, 28:138-142.

Burmeister, G. 1874. Monografía de los glyptodontes en el Museo Público de Buenos Aires. Anales del Museo Público de Buenos Aires, 2:1-412.

Carlini, A.A.; Zurita, A.E.; Gasparini, G. \& Noriega, J.I. 2003. Los mamíferos del Pleistoceno de la mesopotamia argentina y su relación tanto con aquellós del centro norte de Argentina, Paraguay y sur de Bolivia, con los del Sur de Brasil y Oeste de Uruguay: paleogeografía y paleoambientes. Insugeo, Miscelánea, 12:5-12.

Carlini, A.A.; Zurita, A.E. \& Miño Boilini, A. 2008. Reseña paleobiogeográfica de los Xenarthra (Mammalia) del Pleistoceno tardío de la región Mesopotámica (Argentina). Insugeo, 17:259-270.

Cartelle, C. 1999. Pleistocene mammals of the Cerrado and Caatinga of Brazil. In: J.F. Eisenberg \& K.H. Redford (eds.) Mammals of the Neotropics, The University of Chicago Press, p. 27-46.

Cartelle, C. \& Bohórquez, G.A. 1985. Pampatherium paulacoutoi, uma nova espécie de tatu gigante da Bahia, Brasil (Edentata, Dasypodidae). Revista Brasileira de Zoologia, 2(4):229-254.

Cartelle, C.; Câmara, B.G. \& de Prado, P.I.L. 1989. Estudo comparativo dos esqueletos da mão e pé de Pampatherium humboldti (Lund 1839) e Holmesina paulacoutoi (Cartelle 
\& Bohórquez 1985). In: CONGRESSO BRASILEIRO DE PALEONTOLOGIA, 11, 1989. Anais, Curitiba, UFPR, p. 621-631.

Cione, A.L. \& Tonni, E.P. 1999. Bioestratigraphy and chronological scale of upper-most Cenozoic in the Pampean Area, Argentina. Quaternary of South America and Antarctic Peninsula, 12:23-51.

Downing, K.F. \& White, R.S. 1995. The cingulates (Xenarthra) of the Leisey Shell Pit local fauna (Irvingtonian), Hillsborough County, Florida. Bulletin of the Florida Museum of Natural History, 37:375-396.

Edmund, A.G. 1996. A review of Pleistocene giant armadillos (Mammalia, Xenarthra, Pampatheriidae). In: K.M. Stewart \& K.L. Seymor (eds.) Paleoecology and palaeoenvironments of late Cenozoic mammals, University of Toronto Press, p. 300-321.

Faure, M.; Guérin, C. \& Parenti, F. 1999. Découverte d'une mégafaune Holocène à la Toca do Serrote do Artur (aire archéologique de São Raimundo Nonato, Piauí, Brésil). Comptes Rendus de L'Académie des Sciences de Paris, 329:443-448.

Ferrero, B.S.; Brandoni, D.; Noriega, J.I. \& Carlini, A.A. 2007. Mamíferos de la Formación El Palmar (Pleistoceno tardío) de la provincia de Entre Ríos, Argentina. Revista del Museo Argentino de Ciencias Naturales, 9(2):109-117.

Gasparini, G.M. \& Zurita, A.E. 2005. Primer registro fósil de Tayassu pecari (Link) (Mammalia, Artiodactyla) en la Argentina. Ameghiniana, 42(2):473-480.

Gervais, H. \& Ameghino, F.1880. Les mammifères fossiles de l'Ámérique du Sud. Paris-Buenos Aires, Savy-Ignon H., 225 p.

Hoffstetter, R. 1952. Les mammifères pleistocenes de la République de 1'Équateur. Mémoires Societé Géologique de France, 66:1-391.

Hoffstetter, R. 1958. Xenarthra. In: J. Piveteau (ed.) Traité de Paléontologie, Masson et Cie, p. 535-636.

Ihering, H. von. 1891. Correspondencia entre el Dr. Florentino Ameghino y el Dr. Herman Von Ihering. In: E.J. Torcelli (ed.) Obras completas e correspondencia científica, vol. 12, Taller de Impressiones Oficiales, p. 131-134.

Illiger, C. 1811. Prodromis systematis mammalium et avium additis terminis zoographicis utriusque classis. Berlin, C. Salfeld.

Kerber, L. 2008. Paleovertebrados e considerações tafonômicas da FormaçãoTouro Passo (Pleistoceno Superior), oeste do Rio Grande do Sul. Curso de Graduação em Ciências Biológicas, PUCRS/Campus Uruguaiana, Trabalho de Conclusão, $93 \mathrm{p}$.

Kerber, L. \& Oliveira, E.V. 2008a. Presença de Equus (Perissodactyla, Equidae) e Neuryurus (Cingulata, Glyptodontidae), no Quaternário do município de Quaraí, oeste do Rio Grande do Sul. Caderno de Pesquisa, Sér. Biol., 20(3):18-25.

Kerber, L. \& Oliveira, E. 2008b. Sobre a presença de Tapirus (Tapiridae, Perissodactyla) na Formação Touro Passo (Pleistoceno Superior), oeste do Rio Grande do Sul. Biodiversidade Pampeana, 6(1):9-14.

Kerber, L. \& Oliveira, E.V. 2008c. Fósseis de vertebrados da
Formação Touro Passo (Pleistoceno Superior), Rio Grande do Sul, Brasil: atualização dos dados e novas contribuições. Gaea, 4(2):49-64.

Lessa, G. \& Oliveira, E.V. 1996. Occurrence of macraucheniids in the Quaternary of southern, southeastern and northeastern regions of Brazil. Ameghiniana, 33(4):466.

Linnaeus, C. 1758. Systema Naturae per regna tria naturae, secundum Classes, Ordines, Genera, Species, cum characteribus, differentiis, synonymis, locis. $10^{\mathrm{a}} \mathrm{ed}$ Stockholm, Laurentii Salvii, 824 p.

Lopes, R.P.; Buchmann, F.S.C.; Caron, F. \& Itusarry, M.E. 2001. Tafonomia dos fósseis de vertebrados (megafauna extinta) encontrados nas barrancas do arroio Chuí e linha de costa do Rio Grande do Sul, Brasil. Pesquisas em Geociências, 28(2):67-74.

Lund, P. 1839. Blik paa Brasiliens Dyreverden för Sidste Jordomvaeltning. Anden Afhandling: Pattedyrene. Det Kongelige Danske Videnskabernes Selskbas Naturvidenskabelige og Mathematiske Afhandlinger, 8:61-144.

Lund, P. 1840. Blik paa Brasiliens Dyreverden för Sidste Jordomvaeltning. Tredie Afhandling: Forsaettelse af Pattedyrene. Det Kongelige Danske Videnskabernes Selskbas Naturvidenskabelige og Mathematiske Afhandlinger, 8:217272.

Lund, P. 1842. Blik paa Brasiliens Dyreverden för Sidste Jordomvaeltning. Tredie Afhandling: Forsaettelse af Pattedyrene. Det Kongelige Danske Videnskabernes Selskbas Naturvidenskabelige og Mathematiske Afhandlinger, 9:137-208.

McMurtrie, H. 1831. The animal kingdom arranged in conformity with its organization by the Baron Cuvier. New York, Carvill, vol. 1, p. 162-165.

Nodot, L. 1857. Description de un nouveaux genre d'édenté fossile renfermant plusieurs espèces voisines du Glyptodon, etc. Mémoires de l'Académie Impériale des Sciences, Arts et Belles-Lettres de Dijon, 2(5):1-172.

Oliveira, E.V. 1992. Mamíferos fósseis do Quaternário do Estado do Rio Grande do Sul, Brasil. Programa de Pós-graduação em Geociências, Universidade Federal do Rio Grande do Sul, Dissertação de Mestrado, 118 p.

Oliveira, E.V. 1996. Mamíferos Xenarthra (Edentata) do Quaternário do Estado do Rio Grande do Sul, Brasil. Ameghiniana, 33(1):111-128.

Oliveira, E.V. 1999. Quaternary vertebrates and climates from southern Brazil. Quaternary of South America and Antarctic Peninsula, 12:61-73.

Oliveira, E.V. \& Bergqvist, L.P. 1998. A new Paleocene armadillo (Mammallia, Dasypodoidea) from the Itaboraí Basin, Brazil. Asociación Paleontologica Argentina, Publ. Especial, 5:3540 .

Oliveira, E.V.; Dutra, T. \& Zeltzer, F. 2002. Megaterídeos (Mammalia, Xenarthra) do Quaternário de Caçapava do Sul, Rio Grande do Sul, com considerações sobre a flora associada. Geologia Colombiana, 27:77-86.

Oliveira, E.V.; Faccin, J.R. \& Pereira, J.C. 2003. O pampatério Holmesina (Mammalia, Pampatheriidae) no Quaternário do Rio Grande do Sul. Ameghiniana, 40(4):64R. 
Oliveira, E.V. \& Kerber, L. 2009. Paleontologia e aspectos geológicos das sucessões do final do Neógeno no sudoeste do Rio Grande do Sul, Brasil. Gaea, 5(1):21-3.

Oliveira, E.V. \& Pereira, J.C. 2006. Mamíferos xenartros do Sistema Lagunar III, arroio Chuí, Santa Vitória do Palmar, RS, Brasil. Ciência e Natura, Edição Especial:71.

Oliveira, E.V.; Prevosti, F.J. \& Pereira, J. C. 2005. Protocyon troglodytes (Mammalia, Carnivora) in the late Pleistocene of Rio Grande do Sul and their paleoecological significance. Revista Brasileira de Paleontologia, 8(3):215-220.

Owen, R. 1839. Description of a tooth and part of the skeleton of the Glyptodon clavipes, a large quadruped of the Edentate order, to which belongs the tesselated bony armour described and figures by Mr. Clift in the former volume of the Transactions of the Geological Society; with a consideration of the question whether the Megatherium possessed an analogous dermal armour. Transactions of the Geological Society, 2:81-106.

Owen, R. 1845. Descriptive and illustrated catalogue of the fossil organic remains of Mammalia and Aves contained in the Museum of the Royal College of Surgeons of England. London, R. and J.E. Taylor, 391 p.

Paula Couto, C. de. 1939. Paleontologia do Rio Grande do Sul. Revista do Instituto Histórico e Geográfico do Rio Grande do Sul, 76:207-277.

Paula Couto, C. de. 1973. Edentados fósseis de São Paulo. Anais da Academia Brasileira de Ciências, 45:261-275.

Paula Couto, C. de. 1975. Mamíferos fósseis do Quaternário do sudeste brasileiro. Boletim Paranaense de Geociências, 33:89-132.

Paula Couto, C. de. 1979. Tratado de paleomastozoologia. Rio de Janeiro, Academia Brasileira de Ciências, 590 p.

Paula Couto, C. de. 1980. Um tatu gigante do Pleistoceno de Santa Catarina. Anais da Academia Brasileira de Ciências, 52:527-531.

Paula Couto, C. de. 1982. Pleistocene armadillo from Cantagalo, State of Rio de Janeiro. Iheringia, Sér. Geol., 7:65-68.

Paula Couto, C. de. 1983. Fossil Mammals from the Cenozoic of Acre, Brazil. VI-Edentata Cingulata. Iheringia, Sér. Geol., 8:33-34.

Pitana, V.G. \& Ribeiro, A.M. 2007. Novos materiais de Propraopus Ameghino, 1881 (Mammalia, Xenarthra, Cingulata) do Pleistoceno final, Rio Grande do Sul, Brasil. Gaea, 3(2):61-67.

Porpino, K.O. 1999. Estudo dos Cingulata fósseis depositados no Museu Câmara Cascudo, Natal-RN. Anuário do Instituto de Geociências, UFRJ, 22:109-110.

Porpino, K.O.; Santos, M.F.C. \& Bergqvist, L.P. 2004. Registros de mamíferos fósseis no lajedo de Soledade, Apodi, Rio Grande do Norte, Brasil. Revista Brasileira de Paleontologia, 7(3):349-358.

Porpino, K.O.; Fernicola, J.C. \& Bergqvist, L.P. 2008. Pachyarmatherium (Xenarthra, Cingulata) remains from the Late Pleistocene of Northeastern Brazil and its phylogenetic affinities. In: SIMPÓSIO BRASILEIRO DE PALEONTOLOGIA DE VERTEBRADOS, 6, 2008. Boletim de Resumos, Ribeirão Preto, USP, p. 163-164.
Rincón, A. 2003. Los mamíferos fósiles del Pleistoceno de la cueva del Zumbador (fa. 116), Estado Falcón, Venezuela. Boletín de la Sociedad Venezolana de Espeleología, 37:1826.

Rincón, A.D.; White, R.S. \& McDonald, H.G. 2008. Late Pleistocene cingulates (Mammalia: Xenarthra) from Mene de Inciarte tar pits, Sierra de Perijá, Western Venezuela. Journal of Vertebrate Paleontology, 28(1):197-207.

Scillato-Yané, G.J. 1980. Catálogo de los Dasypodidae fósiles (Mammalia, Edentata) de La República Argentina. In: CONGRESO ARGENTINO DE PALEONTOLOGÍA Y BIOESTRATIGRAFÍA/ CONGRESO LATINOAMERICANO DE PALEONTOLOGÍA, 2/1, 1980. Actas, Buenos Aires, UBA, p. 7-36.

Scillato-Yané, G.J.; Carlini, A.A.; Tonni, E.P. \& Noriega, J.I. 2005. Paleobiogeography of the late Pleistocene pampatheres of South America. Journal of South American Earth Sciences, 20:131-138.

Scillato-Yané, G.J.; Tonni, E.P.; Carlini, A.A. \& Noriega, J.I. 1998. Nuevos hallazgos de mamíferos del Cuaternário en el arroyo Toropí, Corrientes, Argentina. Aspectos bioestratigráficos, paleoambientais y paleozoogeográficos. In: CONGRESO LATINOAMERICANO DE GEOLOGIA/ CONGRESO NACIONAL DE GEOLOGÍA ECONOMICA, 10/6, 1998. Actas, Buenos Aires, UBA, p. 263-268.

Simpson, G.G. 1930. Holmesina septentrionalis, extinct giant armadillo of Florida. American Museum Novitates, 442:110.

Ubilla, M. 1985. Mamíferos fósiles, geocronología y paleoecología de la Formación Sopas (Pleistoceno Superior) del Uruguay. Ameghiniana, 22(3-4):185-196.

Ubilla, M.; Perea, D.; Aguilar, C.G. \& Lorenzo, N. 2004. Late Pleistocene vertebrates from northern Uruguay: tools for bioestratigraphic, climatic and environmental reconstruction. Quaternary International, 114:129-142.

Ubilla, M.; Oliveira, E.V.; Rinderknecht, A. \& Pereira, J.C. 2007. The hystricognath rodent Microcavia in the late Pleistocene of Brazil (Rio Grande do Sul, South America) (Mammalia: Caviidae): biogeographic and paleoenvironmental implications. Neues Jahrbuch für Geologie und Paläontologie, Abhandlungen, 247:15-21.

Vizcaíno, S.F.; Perea, D. \& Ubilla, M. 1995. Presencia de Dasypus (Mammalia, Edentata, Dasypodidae) en la Formación Sopas (Pleistoceno tardío) del Uruguay. Distribución cronológica del género. Revista Chilena de Historia Natural, 68:95-99.

Vizcaíno, S.F.; Rinderknecht, A. \& Czerwonogora, A. 2003. An enigmatic cingulata (Mammalia: Xenarthra) from the late Miocene of Uruguay. Journal of Vertebrate Paleontology, 23(40):981-983.

Wagler, J. 1830. Natürliches System der Amphibien, mit vorangehender Classification der Säugetiere und Vögel. Ein Beitrag zur vergleichenden Zoologie. Cotta, München, Stuttgart, and Tübingen, $354 \mathrm{p}$.

Wetzel, R. \& Mondolfi, E. 1979. The subgenera and species of long-nosed armadillos, genus Dasypus L. In: J.F. Eisenberg (ed.) Vertebrate ecology in the Northern Neotropics, Smithsonian Institution Press, p. 43-63. 
Winge, H. 1915. Jordfundne og nulevende Gumlere (Edentata) fra Lagoa Santa, Minas Gerais, Brasilien. E Museo Lundii, 3(2):1-321.

Wolf, T. 1875. Geognostische Mittheilungen aus Ecuador. 4: Kritische Zusammenstellung der in Ecuador stattgefundenen Vulkan-Ausbrüche und Erdleben seit der Zeit der Conquista. Neues Jahrbuch für Mineralogie Geologie und Paläeontologie, 1875:152-170.
Zurita, A.; Scillato-Yané, G.J. \& Carlini, A.A. 2005. Paleozoogeographic, biostratigraphic, and systematic aspects of the genus Sclerocalyptus Ameghino, 1891 (Xenarthra, Glyptodontidae) of Argentina. Journal of South American Earth Sciences, 20:121-129.

Received in March, 2009; accepted in August, 2009. 